\title{
Ameliyathane Kaynaklı Basınç Yaraları Önlenebilir mi?
}

\author{
Esma AYDIN ${ }^{1}$, (iD) Ayşegül SAVCI ${ }^{2}$, (iD) Kevser KARACABAY ${ }^{3}$
}

${ }^{1}$ Hemşire, Bilecik Eğitim ve Araştırma Hastanesi Ameliyathane Birimi, Kütahya Sağlık Bilimleri Üniversitesi, Lisansüstü Eğitim Enstitüsü, Cerrahi Hastalıkları Hemşireliği Anabilim Dalı, Kütahya, Türkiye.

${ }^{2}$ Dr. Öğr., Üyesi, Kütahya Sağlık Bilimleri Üniversitesi, Sağlık Bilimleri Fakültesi, Hemşirelik Bölümü, Cerrahi Hastalıkları Hemşireliği Anabilim Dalı, Kütahya, Türkiye.

\section{$\ddot{\mathbf{O} z}$}

Ameliyathane kaynaklı basınç yarası, ameliyattan sonra 48-72 saat içinde gelişen ve çok yaygın görülen bir sorundur. Sağlık bakım hizmetlerinin kalite göstergelerinden olan basınç yaraları, sağlık hizmetlerindeki gelişme ve yeniliklere karşın tüm Dünya'da sık karşılaşılan önemli sağlık sorunlarından biridir. Basınç yaraları, risk faktörlerinin belirlenmesi, erken teşhis edilmesi ve iyi bir hemşirelik bakımı ile \%90 oranında önlenebilir. Hemşireler ve ameliyathanede çalışan tüm sağlık profesyonelleri ameliyathane kaynaklı basınç yarası için risk oluşturan faktörleri bilmeli, önlemek için gerekli bütün girişimleri uygulamalıdır. Bu derlemede de cerrahi girişim geçiren hastalarda ameliyathane kaynaklı basınç yarası oluşumuna sebep olan risk faktörlerinin ve önlemek için yapılan uygulamaların son çalışmalar ışı̆ı̆ında incelenmesi amaçlanmıştır.

Anahtar Sözcükler: Basınç Yarası, Cerrahi Girişim, Ameliyathane Hemşireliği.

\section{Abstract \\ Can Pressure Ulcers From The Operatıng Room Be Prevented?}

Operating room-induced pressure ulcer is a common problem that develops within the first 48-72 hours after surgery. Pressure ulcers, which are considered one of the quality indicators in health care, are one of the most common and important health problems in the world, despite Development and innovation in health care. Pressure ulcer can be prevented by $90 \%$ by identifying risk factors, early detection, and good nursing care. All health professionals working in the operating room, especially nurses, should know the risk factors for the pressure ulcer caused by the operating room and implement the necessary initiatives to prevent it. In this review, it was aimed to examine the risk factors and prevention practices involved in the development of pressure ulcers in patients undergoing surgical intervention in the light of recent studies. Key Words: Pressure Ulcer, Surgical Intervention, Operating Room Nursing.

Geliş Tarihi / Received: 04.04.2021 Kabul Tarihi / Accepted: 30.06.2021

Correspondence Author: Hemşire, Bilecik Eğitim ve Araștırma Hastanesi Ameliyathane Birimi, Kütahya Sağlık Bilimleri Üniversitesi, Lisansüstü Eğitim Enstitüsü, Cerrahi Hastalıkları Hemşireliği Anabilim Dalı, Kütahya, Türkiye. Telefon: +90 531690 1620 E-posta: esma.aydin.2608@ gmail.com

Cite This Article: Aydın E, Savcı A, Karacabay K. Ameliyathane Kaynaklı Basınç Yaraları Önlenebilir mi?. Dokuz Eylül Üniversitesi Hemşirelik Fakültesi Elektronik Dergisi. 2021; 14(4): 442- 452 
D ışarıdan gelen fiziksel bir basınç sonucunda oluşan doku bütünlüğündeki bozulma için "basınç yarası", "basınç ülserleri”, "basınç hasarı", "yatak yarası", "dekübit ülseri”, "dekübit” gibi pek çok terim kullanılmaktadır (1). Ülkemizde ise bu terimler arasından basınç yarası terminolojisi kullanımı tercih edilmektedir $(1,2)$. Ulusal Basınç Ülseri Danışma Paneli (National Pressure Ulcer Advisory Panel-NPUAP), basınç yarasını, "genellikle kemik çıkıntısı üzerinde tıbbi veya diğer bir cihazla ilgili cilt ve/veya altta yatan yumuşak dokunun lokalize hasarı" olarak tanımlamıştır (1). Basınç yarası oluşumuna sebep olan temel faktörler; basınç, sürtünme, sıkışma ve yırtılmadır. Dişsal basınç kuvvetinin, kapiller basınç değerini aştığı durumlarda, kapiller perfüzyon bozularak, dokular yeterli besin maddeleri ve oksijenden yoksun kaldığı için iskemi meydana gelir (3). İskemiye bağlı dejeneratif değişiklikler deri, subkutan doku, kas ve fasya gibi tüm katmanları etkilemekte ve basıncın 6 saatten fazla sürmesi durumunda yara ile sonuçlanabilmektedir (4). Sağlık bakım hizmetlerinde önemli bir sorun olan basınç yaraları, Amerika'da hastanede yatan hastalarda \%5-15 oranında görülmektedir (5). Hindistan ve Kuzey Kore'de bu oran; \%19.2, Avusturalya'da \%27.9 olarak bildirilmiş̧ir $(6,7)$. Ülkemizde, konu ile ilgili Eftelli ve Güneş (2014) çalışmalarında basınç yarası insidansını yaklaşık \%28 olarak bildirmişlerdir (8). Yapılan diğer çalışmalarda da oranın \%20-35 arasında olduğu görülmektedir $(9,10)$. Sıklıkla karşı karşıya kaldığımız basınç yarasının sağlık çalışanları, hasta ve hastane için birçok olumsuz sonucu vardır. Bireylerin yaşam kalitesini olumsuz etkileyip, ağrı, bakteriyel enfeksiyon, sepsis ve septik şok gibi komplikasyonlara neden olmaktadır (11). Dolayısıyla mortalite oranını, hastanede kalma süresini ve tedavi giderlerini de arttırmaktadır (11). Amerika'da basınç yarasının yıllık maliyeti, NPUAP 2016 yılındaki verilerine göre; 2.2-3.6 milyar dolar arasındadır (1). Bu çalışmada, ameliyatahane kaynaklı basınç yaralarının risk faktörleri ve önleme yaklaşımları kanıta dayalı uygulamalar ışığında sunulmuştur.

\section{Ameliyathane Kaynakı Basınç Yaraları}

\section{Gelişme}

Ameliyathane kaynaklı basınç yarası, Amerika Ameliyathane Hemşireler Derneği (Association of Perioperatie Registered Nurses -AORN) tarafından ameliyat sonrası ilk 48- 72 saat içinde gelişen basınç yarası olarak tanımlanmaktadır (12). Gefen'in bildirdiğine göre cerrahi girişim uygulanan hastalarda basınç yarası insidansını 1970'lerin başında ilk kez Hicks, 2 saat ve üzeri ameliyat süresi olan 100 hastayla yaptığı çalışmasında, 13 hastada basınç yarası geliştiğini göstererek ortaya koymuştur (13). Ameliyathane kaynaklı basınç yarası insidansının; Portekiz'de \%12.2 (14), İtalya'da \%12.7 (15), Amerika Birleşik Devletleri'nde (ABD) \%13 (16) olduğu bildirilmektedir. Ülkemizde ise Çelik ve ark. 2017 yılında, 151 cerrahi hastası ile yaptıkları çalışmada basınç yarası görülme oranını $\% 40.40$ olarak saptamışlardır (17).

\section{Ameliyathane Kaynaklı Basınç Yaralarında Risk Faktörleri}

Basınç yaralanmalarını önlemek ve olumsuz etkilerini azaltmak için, basınç yarasına neden olabilecek risk faktörlerinin doğru değerlendirilmesi önemlidir. Cerrahi girişim geçiren hastalarda basınç yarası oluşumunda rol oynayan birçok risk faktörü bulunmaktadır (18). Ameliyathane Hemşireler Birliği cerrahi girişim uygulanan hastalarda basınç yarası gelişimine neden olan dış (ekstrensek) ve iç (intrensek) faktörleri tanımlamıştır (19). Dış faktörler; Aşırı uniaksiyal basınç, pozisyon verme sırasında ve sonrasında olabilecek sürtünme (friksiyon), yırtılma, makaslama, odanın sıcaklı̆ğ ve odanın nemidir (20). İç faktörler ise ileri yaş, beslenme yetersizliği (düşük albümin seviyesi, düşük beden kitle indeksi, kas güçsüzlügü), düşük beden kütle indeksi (BKİ), obezite, uzamış immobilizasyon, basıncın neden olduğu ağrıyı hissetmeme, duyusal kayıplar, nöral fonksiyon kayıpları, kronik hastalık varlığı, diyabetes mellitus, ödem, fekal inkontinans, infeksiyon, düşük hemoglobin seviyesi ve sigara kullanımı olarak bildirilmiştir $(1,18,19,21)$ (Tablo 1).

Tablo 1. Cerrahi girişim uygulanan hastalarda basınç yarası risk faktörleri

\begin{tabular}{ll}
\hline Dışsal Risk Faktörleri & İçsel Risk Faktörleri \\
\hline Aşırı uniaksiyal basınç & İmmobilizasyon \\
Sürtünme (friksiyon) & Duyusal kayıp \\
Yırtılma & Yaş \\
Makaslama & Kronik hastalıklar \\
Odanın sıcaklığı & Vücut tipi \\
Odanın nemi & Beslenme \\
& Düşük BKİ \\
& Obezite \\
& İnfeksiyon \\
& İnkontinans \\
& Sigara kullanımı \\
& Düşük hemoglobin düzeyi \\
\hline
\end{tabular}

Ayrıca bunlara ek olarak ameliyat öncesi risk faktörleri; ileri yaş, çocuk hastalar, artrit veya protezi olan hastalar, diyabet ve dolaşım bozukluğu, obezite, risk değerlendirme skorunun yüksek olması, braden skalası değerlendirme puanının 20'nin altında olması, düşük hemoglobin düzeyi $(<12 \mathrm{~g} / \mathrm{dl})$, düşük albümin düzeyi $(<3 \mathrm{mg} / \mathrm{dl})$, malnutrisyon, ilaçlar (steroid vb), kronik hastalık öyküsü, nöral fonksiyon kaybı, immobilizasyon, nemli deri ve sigaradır $(18,21)$. İntraoperatif dönemde ortaya çıkan basınç yarası risk faktörleri de şu şekildedir; anestezinin türü, sedasyon, vazopressör ilaç kullanımı, ameliyatın tipi, ameliyat süresinin uzun olması, kullanılan ameliyat masası, hastanın ameliyat pozisyonu (basıncı azaltıcı pozisyon verilmemesi), kullanılan pozisyon aletleri, destek yüzeyi ile hasta 
arasında örtü olması, cilt hazırlığı için kullanılan solüsyonlar, derinin ıslak ve nemli olması, vücut ısısı (hipotermihipertermi), hipotansiyon, ekstra korporeal dolaşım, immobilizasyon süresi ve ssıtıcı battaniye kullanımıdır $(1,18,21)$. Ameliyat sonrası için risk faktörleri ise; yetersiz oral beslenme, vazokonstrüksiyona yol açan ilaçlar, immobilizasyon, ameliyat sonrası kullanılan yatağın tipidir (1, 18-21) (Tablo 2).

Tablo 2: Ameliyat öncesi, sirası ve sonrası döneme özgü basinç yarası risk faktörleri

\begin{tabular}{|c|c|c|}
\hline Ameliyat Öncesi & Ameliyat Sırası & Ameliyat Sonrası \\
\hline $\begin{array}{l}\text { İleri yaş ( } 70 \text { yaş ve üzeri) } \\
\text { Çocuk hastalar } \\
\text { Artrit veya protezi olan } \\
\text { hastalar } \\
\text { Obezite } \\
\text { Diyabet ve dolaşım } \\
\text { bozukluğu } \\
\text { Risk değerlendirme skorunun } \\
\text { yüksek olması } \\
\text { Braden skalası değerlendirme } \\
\text { puanının 20’nin altında } \\
\text { olması } \\
\text { Düşük hemoglobin düzeyi } \\
\text { (<12g/dl) } \\
\text { Düşük albümin düzeyi } \\
\text { (<3mg/dl) } \\
\text { Beslenme yetersizliği } \\
\text { İlaç kullanımı (steroid } \\
\text { ve/veya vazoaktif ilaç) } \\
\text { Kronik hastalık öyküsü } \\
\text { Nöral fonksiyon kaybı } \\
\text { İmmobilizasyon } \\
\text { Nemli deri } \\
\text { Sigara }\end{array}$ & $\begin{array}{l}\text { Anestezinin türü } \\
\text { Ameliyatın süresi } \\
\text { Ameliyat pozisyonu ve } \\
\text { kullanılan pozisyon } \\
\text { aletleri } \\
\text { Ameliyat masası } \\
\text { Islak ve nemli deri } \\
\text { Cilt hazırlı̆̆ı için } \\
\text { kullanılan solüsyonlar } \\
\text { Hipotansiyon } \\
\text { Ekstra korporeal dolaşım } \\
\text { Hipotermi, hipertermi } \\
\text { Isıtıcı battaniye } \\
\text { kullanımı } \\
\text { İmmobilizasyon } \\
\text { Destek yüzeyi ile hasta } \\
\text { arasında örtü olması }\end{array}$ & $\begin{array}{l}\text { Oral beslenmede yetersizlik } \\
\text { Vazokonstrüksiyona yol } \\
\text { açan ilaçlar } \\
\text { İmmobilizasyon } \\
\text { Kullanılan yatağın tipi }\end{array}$ \\
\hline
\end{tabular}

Basınç yaralarının önlenmesi, her sağlı bakım biriminde önemli olup özellikle de cerrahi birimlerde yüksek önceliğe sahiptir (19). Cerrahi hastaları, uzun süren ameliyatlar sırasında yoğun ya da uzun süreli basıncın etkisinde kaldıklarından basınç yarası gelişme riski altındadırlar (19). Hastanın ameliyat sırasındaki pozisyonu ameliyat masasının hasta üzerine yaptığı basınçta etkili olup özellikle hastanın kemik çıkıntıları olan beden bölgeleri daha fazla etkilenmektedir (22). Cerrahi işlemin türüne göre basınç yarası oluşum insidansına bakıldığında; kardiyak cerrahi de $\% 29.5$, ortopedik cerrahi de \%20-55, genel cerrahi ve göğüs cerrahisin de \%13-29.3, üriner sistem cerrahisin de \%14.417 ve damar cerrahisin de \%9.8-16 arasında olduğu bildirilmiştir (23). Kalp cerrahisi girişimlerinde uygulanan ekstrakorporeal dolaşım doku perfüzyonunun bozulmasına yol açtığından basınç yarası gelişimi için risk oluşturmaktadır (22). Scarlatti ve ark. (2011) tarafından 199 hasta ile yapılan bir çalışmada genel anestezi alan hastalarda basınç yarası gelişiminin, lokal anestezi alan hastalara oranla dört kat daha fazla olduğu saptanmıştır (24). Ameliyat sırası ve sonrasında düşük kan basıncının basınç yarası gelişimini hızlandırdığı saptanmıştır. Düşük kan basıncı, kan akımını azaltarak dokunun basınca toleransını azaltıp, kısa sürede basınç yarası oluşumuna sebep olmaktadır (25). Doku perfüzyonunu olumsuz etkileyen diğer bir durum hipertansiyon olup, basınç yarası gelişim riskini arttırmaktadır (22). Cerrahi işlem sırasında, noradrenalin, epinefrin gibi vazopressör ilaç kullanımı nedeniyle hemostazis ve doku perfüzyonu bozulup, doku hasarı meydana gelir (25). Ameliyat sırasında vücut ısı değişimleri, periferik damarlarda vazodilatasyon ve vazokontrüksiyonla birlikte basınç yarası gelişimine sebep olmaktadır. Hipotermi, damarlarda vazokontrüksiyona sebep olup, dolaşımın azalmasına, oksijen, besin ve metabolik atıkların transferinde bozulmaya ve doku hasarına yol açmaktadır $(18,26)$. Fred ve arkadaşları anestezi verildikten sonraki bir saat içinde hastalar 1sıtılmadığında vücut ısılarında $1.80^{\circ} \mathrm{C}^{\prime}$ lik bir azalma olduğu ve bunun basınç yarası gelişme oranını $\% 20.20$ arttırdığını bildirmişlerdir (26). Yüksek vücut 1sısı ise, metabolizma hızını, oksijen gereksinimini ve yüzeyin doku ile arasındaki basıncı artırmakta ve basınç yarasına neden olabilmektedir. Vücut 1sısında $1{ }^{0} \mathrm{C}$ 'lik artış dokuların oksijen ve enerji gereksiniminde $\% 10$, yüzey ile doku arasındaki basınçta ise $12-15 \mathrm{mmHg}$ 'lık, bir artışa neden olarak basınç yarası gelişimini kolaylaştırmaktadır $(27,28)$. Bunların yanı sıra cerrahi işlem uygulanan hastalarda cilt hazırlığı için kullanılan solüsyonlar, kanamalar ve ameliyat sırasında yapılan yıkamalar hastanın altında birikerek nem oluşturması da basınç yarası gelişiminde rol oynamaktadır. Nem, cilt pH'sını etkileyerek, derinin basınç, sürtünme ve yırtılma gibi fiziksel etmenlere karşı olan direncini azaltmaktadır. Neme uzun süre maruz kalan yüzeyel tabakalarda gerçekleșen yumuşama, basınca maruz kalırsa kan akımında azalma ve sonuç olarak da doku hasarı görülmektedir $(18,27)$.

Hastanın ameliyat sırasındaki pozisyonu ve ameliyat masasının hastaya yaptığı basıncın da yara gelişiminde etkili olduğu saptanmıştır (29). Hastaya pozisyon verilmesinin amacı; cerrahi alana kolay ulaşmak, kardiyovasküler ve solunumsal değişiklikleri, göğüs kafesine baskıyı ve sinir hasarlarını önlemek, hastanın güvenliğini ve konforunu sağlamaktır. Ancak buna rağmen, özellikle hastanın kemik çıkıntılarının olduğu vücut bölgeleri basınçtan daha çok etkilenmektedir $(22,29)$. Baş ve boyun cerrahisi geçiren hastalarda ise verilen pozisyona bağlı olarak \%37 oranında 
sakral bölgede, basınç yarası geliştiği belirtmiştir (18). Abdominal cerrahi girişimlerinde tercih edilen supine pozisyonu basınç yarası gelişim riskini arttırmaktadır (22). Ameliyat süresi uzadıkça kemik doku üzerindeki yumuşak dokuların basınca maruz kalma durumu artmaktadır (30). Wright ve ark. (2014), ameliyat süresi 12 saat ve üzeri olan hastalarda basınç yarası geliştiğini ifade etmiştir (31). Ameliyat esnasında hastaya verilen pozisyonlardan örnekler ve basınç açısından riskli bölgeler Şekil 1 ve Tablo 3 'te gösterilmiştir. Tüm bu etmenler nedeniyle ameliyat olan hastalar cerrahi girişim sırasında basınç yarası gelişimine eğilimlidirler (32).

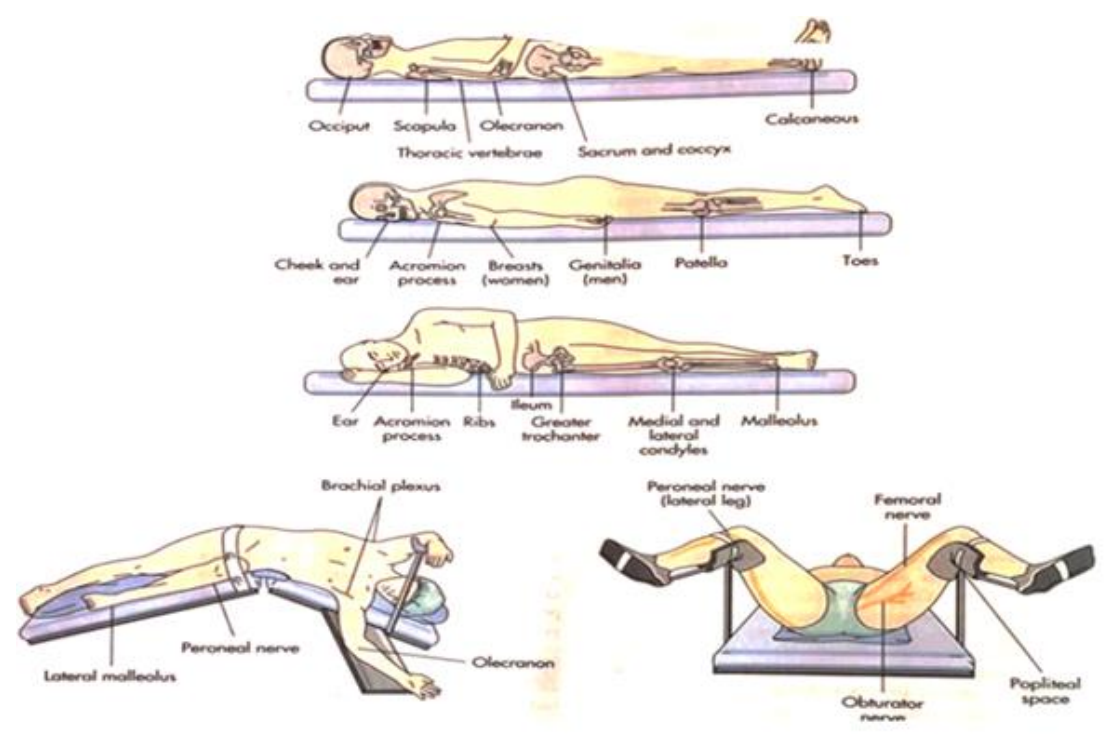

Şekil 1. Ameliyat Sırasında Hastaya Verilen Pozisyonlar ve Basınç Açısından Riskli Bölgeler (33)

Tablo 3. Ameliyat Strasında Hastaya Verilen Pozisyonlar ve Basınç Açısından Riskli Bölgeler

$\begin{array}{ccccccc}\text { Supine } & \text { Prone } & \text { Lateral } & \text { Semi-fowler } & \text { Litotomi } & \text { Trendelenburg } & \text { Kraske } \\ \text { Pozisyonu } & \text { pozisyonu } & \text { pozisyonu } & \text { pozisyonu } & \text { pozisyonu } & \text { Pozisyonu } & \begin{array}{c}\text { (jackknif) } \\ \text { pozisyonu }\end{array} \\ & & & & & & \end{array}$

\begin{tabular}{lllllll}
\hline Oksipital & Frontal bölge & Fasiyal & Oksipital bölge & Oksipital & Oksipital bölge & Temporal \\
bölge & Gözler & bölge & Omuzlar & bölge & Brakial pleksus & Göz \\
Torasik & Kulaklar & Kulaklar & İskial & Omuzlar & Torasik vertebra & Burun \\
vertebra & Çene & Omuzlar & tüborositler & Skapula & Omuzlar & Kulak \\
Omuzlar & Omuzları̈ ön & Aksilla & Kalça & Sakrum/ & Dirsekler & Çene \\
Dirsekler & kismı & Kalça & Topuk & koksiks & Kollar & Uyluk \\
Kollar & Memeler & Dizler & & Topuklar & Lomber bölge & Dizler \\
Lomber bölge & Genital & Bacaklar & & Kalça & Sakrum/koksiks & Parmaklar \\
Sakrum/ & organlar & Ayaklar & & Ayaklar & İliak kemik \\
koksiks & Krista iliaka & Ayak & & Topuklar & Göğüs \\
Ayaklar & Dizler & bilekleri & & & Genital \\
Topuklar & Ayaklar & & & & organlar \\
& & & & & \\
\hline
\end{tabular}

Ameliyat pozisyonları arasında en riskli pozisyonlar; supine pozisyonu ve prone pozisyonudur. Basınç yaralarının en s1k görüldüğü vücut bölgeleri supine pozisyonunda; sakrum/koksiks ve topuklar, prone pozisyonunda ise; alın, çene, genital organlar ve krista iliakadır $(22,29)$. Hastaya güvenli ameliyat pozisyonu verilmesi cerrahi ekibin sorumluluğudur. Doğru ameliyat pozisyonu verilebilmesi için cerrahi ekip, ameliyat türünü, ameliyat için istenilen pozisyonu ve bu pozisyonun etkilerini bilmeli ve pozisyona bağlı oluşabilecek komplikasyonları önlemek için gerekli girişimleri uygulamalıdır.

\section{Ameliyathane Kaynaklı Basınç Yaralarının Önlenmesi ve Hemşirenin Rolü}

Basınç yarasının önlenmesinde, yaraların gelişmesine neden olan etkenlerin belirlenmesi, etkenlere yönelik hemşirelik girişimlerinin planlanması ve uygulanması gerekmektedir. Basınç yaralarına yönelik eğitim almış yara bakım hemşireleri olmak üzere tüm hemşireler basınç yaraların önlenmesi ve bakımından sorumludur (34).

\section{Ameliyathane Kaynaklı Basınç Yaralarının Değerlendirilmesi}

Ameliyathane kaynaklı basınç yaralarını önlemede asıl amaç doku bütünlüğünün korunup devamlılığının sağlanmasıdır. Erken dönemde kapsamlı bir risk değerlendirmesi yapılmalıdır (1). Bu amaçla Pan Pasific Basınç Yaralanması Birliği [Pan Pasific Pressure Injury Alliance (PPPIA)], Ulusal Basınç Ülseri Danışma Paneli [National Pressure Ulcer Advisory Panel (NPUAP)] ve Avrupa Basınç Ülseri Danışma Paneli [European Pressure Ulcer Advisory Panel (EPUAP)] oluşturdukları rehberlerde, basınç yarası risk değerlendirmesinde kapsamlı klinik ve cilt değerlendirmesinin yanı sıra, hastaya özel geçerlilik ve güvenilirliği olan risk ölçüm aracı kullanılması gerektiğini bildirmişlerdir (1). Literatürde, basınç yarası riskini ve basınç yaralarını değerlendirmeye yönelik pek çok sayıda farklı ölçüm araçları vardır $(19,35,36)$. 
Bunlardan en sık kullanılanlar Tablo 4’te gösterilmiştir.

Risk değerlendirme

Hemşireler bireyi bütüncül olarak değerlendirip, deri bütünlüğünü bozan, doku oksijenlenmesini etkileyen mevcut ve olası riskleri cerrahi girişim öncesi, sırası ve sonrasında belirlemelidir (1,37). Ameliyat öncesi dönemde, hastanın; yaşı, BKİ, derinin durumu (skapula, oksipital bölge, omuz, dirsek, kafatası, temporal bölge ve ayaklar), alerjileri, kronik hastalıkları, vücut sıcaklı̆̆ı, laboratuvar sonuçları, hareket kısıtlılı̆̆, kalp cihazları, protez, ortopedik implantlar, kateterler, drenler gibi cihazların varlığı, periferik nabızları, ağrı algılama durumu, bilinç düzeyi, psikososyal ve kültürel faktörleri değerlendirilmelidir $(38,39)$. Hastanın yeterli besin, vitamin, mineral, sıvı alımı sağlanmalı, hipovolemi, sigara kullanımı, stres varlığı gibi faktörler açısından hastanın ameliyat öncesi hazırlığı yapılmış olmalıdır (18). Ameliyat öncesi dönemde; 70 yaş ve üzeri hastalar, çocuk hastalar, artrit veya protezi olan, ameliyat süresi 4 saatten fazla olan, kaşektik ya da beslenme bozukluğuna sahip, diyabet ve dolaşım bozukluğu olan, ameliyat öncesinde Braden skalası değerlendirmesinden 20'nin altında puan alan hastalarda ek önlemler gerekebilir (40). Ameliyat sırasında; anestezinin türü, ameliyatın süresi ve istenen ameliyat pozisyonu değerlendirilmelidir $(38,41)$. Son kontrol (Time out) listesi de hastada oluşabilecek riskleri, ameliyat süresinde uzamaya sebep olan faktörleri belirlemek, pozisyon değişikliği yapmak ve basınç yarası açısından hastanın cildini kontrol etmek için cerrahi ekibe firsat sağlar (42). Son kontrol listesi uygulamasının uzun süreli cerrahi işlem geçiren tüm hastalar için faydalı olabileceği yapılan çalışmalarda belirtilmektedir (42). Güvenilir bir ölçeğin kullanılması da risk faktörlerinin belirlenmesinde çok önemlidir (Tablo 4).

Normoterminin săglanmasl

Normoterminin $\left(36^{\circ} \mathrm{C}-37.7^{\circ} \mathrm{C}\right)$ sağlanması için, ameliyat odası, hastalar uygun olarak 1sıtılmalı, preoperatif hazırlık döneminde ısı kaybını azaltmak için hasta örtülmelidir. Hasta boyama solüsyonlarının ısısına dikkat edilmeli, IV sıvılar, yıkama solüsyonları, kan ürünleri, protokollere uygun olarak ssıtılarak verilmelidir (18). Kan akımının az olacağı öngörülen bölgelerde sıcak şilte veya ısıııcı battaniyeler kullanılabileceği de belirtilmiştir $(1,12,18)$. 
Tablo 4. Basınç Yarası Riskini ve Basınç Yaralarını Değerlendirmede Kullanılan Ölçüm Araçları Basınç Yarası Risk Değerlendirme Skalaları

\begin{tabular}{|c|c|c|}
\hline & $\begin{array}{c}\text { Kullanılan } \\
\text { hasta grubu }\end{array}$ & Alt başlıklar \\
\hline Braden Skalası & $\begin{array}{l}\text { Tüm klinikler } \\
\text { (yetişkin) }\end{array}$ & $\begin{array}{l}\text { Duyusal alg1, nem, aktivite, hareketlilik, } \\
\text { beslenme, sürtünme ve yırtılma }\end{array}$ \\
\hline Norton Skalası & $\begin{array}{l}\text { Hastanede } \\
\text { yatan geriatrik } \\
\text { hasta grubu }\end{array}$ & $\begin{array}{l}\text { Motivasyon, yaş, cildin durumu, ek hastalıklar, } \\
\text { fiziksel durum, mental durum, aktivite, } \\
\text { hareketlilik, inkontinans }\end{array}$ \\
\hline Waterlow Ölçeği & $\begin{array}{l}\text { Tüm klinikler } \\
\text { (yetişkin) }\end{array}$ & $\begin{array}{l}\text { Beden kitle indeksi, riskli deri bölgeleri, } \\
\text { hastanın cinsiyeti ve yaşı, malnütrisyon } \\
\text { durumu, kontinans, hareketlilik, doku } \\
\text { malnütrisyon durumu, nörolojik bozukluklar, } \\
\text { majör cerrahi ya da travma durumu }\end{array}$ \\
\hline Gosnell Skalası & $\begin{array}{l}\text { Geriatrik } \\
\text { hastalar }\end{array}$ & $\begin{array}{l}\text { Mental durum, kontinans, hareketlilik, aktivite, } \\
\text { beslenme }\end{array}$ \\
\hline $\begin{array}{l}\text { Buçh Pediatrik } \\
\text { Basınç Yarası Risk } \\
\text { Tanılama Aracı }\end{array}$ & Çocuk hastalar & $\begin{array}{l}\text { Hareketlilik, dehidratasyon ve ödem, dokuların } \\
\text { perfüzyon durumu, ek hastalıklar, cerrahi } \\
\text { müdahale geçirme durumu, bilinç, yaş, } \\
\text { hastanede yatış günü, mekanik ventilasyon } \\
\text { şekli, beslenme, anemi, araç-gereç, inkontinans, } \\
\text { ilaç tedavileri, nemlilik, vücut isısı }\end{array}$ \\
\hline
\end{tabular}

Ameliyatahaneye Özgü Basınç Yarası Risk Değerlendirme Skalaları

\begin{tabular}{|c|c|c|}
\hline & $\begin{array}{c}\text { Kullanilan } \\
\text { hasta grubu }\end{array}$ & Alt başlıklar \\
\hline $\begin{array}{l}\text { Munro Basınç } \\
\text { Ülseri Risk } \\
\text { Değerlendirme } \\
\text { Ölçeği } \\
\text { (AORN) }\end{array}$ & $\begin{array}{l}\text { Ameliyattan } \\
\text { önce, ameliyat } \\
\text { siras1, } \\
\text { ameliyat } \\
\text { sonrası cerrahi } \\
\text { hastaları }\end{array}$ & $\begin{array}{l}\text { Yaş, BKİ, perioperatif kan kaybı, anestezi tipi, } \\
\text { ameliyat süresi, hipotansiyon, nem, vücut } \\
\text { sıcaklı̆̆ı, komorbit hastalık varlığı, ASA* skoru, } \\
\text { ameliyat masası destek yüzeyi tipi, ameliyat } \\
\text { öncesi mobilizasyon durumu, ameliyat } \\
\text { pozisyonu, beslenme durumu, kilo kaybı }\end{array}$ \\
\hline $\begin{array}{l}\text { Scott Triggers } \\
\text { Ölçeği }\end{array}$ & $\begin{array}{l}\text { Ameliyat } \\
\text { öncesi, } \\
\text { ameliyat } \\
\text { siras1, } \\
\text { ameliyat } \\
\text { sonrası cerrahi } \\
\text { hastaları } \\
\end{array}$ & $\begin{array}{l}\text { Yaş, serum albumin seviyesi, beden kitle } \\
\text { indeksi, ASA skoru ve tahmini ameliyat süresi }\end{array}$ \\
\hline $\begin{array}{l}\text { 3S Ameliyathane } \\
\text { Basınç Yarası Risk } \\
\text { Tanılama Ölçeği }\end{array}$ & $\begin{array}{l}\text { Ameliyat } \\
\text { öncesi, } \\
\text { ameliyat } \\
\text { siras1, } \\
\text { ameliyat } \\
\text { sonrası cerrahi } \\
\text { hastaları } \\
\end{array}$ & $\begin{array}{l}\text { Cildin durumu, ameliyat öncesi mobilizasyon } \\
\text { durumu, BKI, ameliyat süresi, ameliyat sirasında } \\
\text { kan kaybı, ameliyat sırasındaki pozisyonu, } \\
\text { ameliyat sırasındaki vücut sicaklığı }\end{array}$ \\
\hline
\end{tabular}

\section{Ameliyatın süresi}

Hastanın ameliyat süresi ve basınç yarası oluşumuyla ilgili yapılan çalışmalarda ameliyat masasında geçirilen sürenin, basınç yarası oluşumunda belirleyici bir faktör olduğu görülmüştür. Fakat cerrahi süre değiştirilemeyeceği için basınç süresi ve makaslanma kuvvetini azaltmak amacıyla, ameliyat masaları üzerine basıncı dengeli bir şekilde ve yeniden dağıtabilen destek yüzeyler kullanılmalıdır $(1,12,18)$.

Deri hazırlı̆̆

Ameliyat bölgesinde cilt antisepsisi yapılırken fazla solüsyon kullanmaktan kaçınılmalı, tamponlarda ki fazla solüsyonlar tasa akacak şekilde sıkılmalı, hastanın alt kısmında veya ameliyat masasının üzerinde birikecek şekilde akıtılmamalıdır $(18,27)$.

Ameliyat masalart

Hastalar ameliyat boyunca hareketsiz kalmakta ve dokular arası basınç artmaktadır. Ameliyathanede ki basınç yaralarını önleme konusunda ameliyat masaları önemli bir yer tutmaktadır (18). Masalar cerrahi girişimlere uygun olarak istenilen 
ve gereken şekilde ayarlanmalıdır. Ameliyat masaları baş, gövde ve bacak olmak üzere üç ya da daha fazla bölümden oluşur. Bunların her biri istenilen pozisyona göre değiştirilebilir, bükülebilir veya uzatılabilir özellikte olmalıdır (1).

Pozisyon araçları ve destek yüzeyler

Ameliyat masası destek yüzeyleri, hastanın sabitlenmesine, desteklenmesine, hasta ile zemin arasında oluşacak basıncın daha geniş bir alana dağılmasına yardımcı olur. Böylece doku perfüzyonu sürdürülebilir, olası sinir hasarı önlenebilir ve hasta güvenliği sağlanabilir $(30,40)$. Destek yüzeyler şilte, minder, yastık ve yatak gibi objeleri içerir. Bu amaçla jel, köpük, viskoelastik, hava içerikli gibi çeşitli destek yüzeyler (kol tahtası, baş desteği, sabitleme kemeri, masa uzatma aracı, yastık, pozisyon destek pedi vb.) bulunmaktadır (30). Ameliyat pozisyonu verilirken, uygun araçlar ve yüzeyler kullanılmalı, pozisyon verme ve taşıma araçlarının aralıklı kontrolü sağlanmalı, çalışır durumda olmalı, üretici firmanın talimatları doğrultusunda güvenli bir şekilde kullanılmalıdır (40). Tercih edilen pozisyon araçları ve destek yüzeyleri; hastayı istenilen pozisyonda tutabilen, ağırlığa dayanıklı olan, cilde zarar vermeyen, alerjik olmayan, 1sıya ve neme karşı dayanıklı, kullanımı kolay ve düşük maliyetli olma özelliklerine sahip olmalıdır (40). Uygun ameliyathane şiltesinin en önemli özelliği, yüzey basıncını dengeli dağıtmasıdır (43). NPUAP bir destek yüzeyinin "doku yüklerinin yönetimi için basıncı dağıtmak üzere tasarlanmış özel bir cihaz, mikro klima ya/ya da diğer terapötik işlevlere" sahip olması gerektiğini belirtmiştir. Ameliyat pozisyonu verilirken de NPUAP'nin önerilerine uygun araçlar ve yüzeyler kullanılmalıdır (1). Hastaların yerleştirilmesi sırasında destek yüzeylerinin etkinliğini azaltıp, ek baskıya neden olduğundan çarşaf ve battaniyeler kullanılmamalıdır. Hastanın altındaki çarşaflar kırışmamalı, katlanmamalıdır. Hastaların ameliyat yatağına yerleştirilmesinde, yataktan alınmasında veya pozisyon değiştirme sırasında hastanın cildinde makaslama ve sürtünmeye neden olabileceğinden, hastanın sürüklenmemesine özen gösterilmelidir (41).

Pozisyon verme

Cerrahi işlem sırasında verilen pozisyon kapiller kan akımında azalma sonucu doku hasarına neden olmaktadır. Ameliyat sırasında hastalara verilen farklı pozisyonda basınca maruz kalan vücut bölgeleri değişmektedir. Pozisyon, cerrahi girişime uygun olarak, cerrahiye özel ve doğru şekilde (derinin sürtünme, yırtılma kuvvetine maruz kalmasını önleyerek), eğitimli personel tarafindan verilmelidir $(18,44)$. Pozisyon verirken hastanın yaşı, kilosu, boyu, derinin durumu, kas iskelet sistemi hastalıkları, kronik hastalık öyküleri, uygulanacak anestezinin türü, protez, drenaj sistemi, tüp ve katater varlığı bilinmelidir $(18,44,45)$.

Topukların ameliyat masasına temasının kesilmesi ve dizlerin hafiffleksiyonda tutulması

Cerrahi işlem sırasında topuklar elevasyona alınarak, topukların yatak yüzeyine değmesi engellenmelidir (39). Aşil tendonuna baskı yapmaksızın basıncı ortadan kaldırmak amacıyla topuk asma cihazları kullanılır. Topuk asma cihazları, uzun süreli kullanım için tercih edilir. Bu uygulamalar ile ilgili olarak daha fazla kanıta gereksinim olduğu belirtilmektedir. Topuk derisi düzenli olarak gözlenmelidir (39). Bireyin topukları, aşil tendonuna olan basınc1 engelleyip, bacakların ağırlığını tamamen dağıtacak şekilde elevasyona alınmalıdır. Topukların ameliyat masası ile teması kesilirken dizler, $5^{\circ}$ ila $10^{\circ}$ fleksiyonda olmalıdır (46). Özellikle aşil tendonuna yüksek basınçtan kaçınılması gerekir. Topukları yükseltmek amacıyla köpük yastık veya köpük minderler kullanılabilir. Topuk yükseltmek için kullanılan destek yüzeyler baldırın uzunluğunda olmalıdır (39).

Pozisyon sonrası değerlendirme

Cerrahi ekip, hastanın vücuduna yaslanarak dışarıdan bası yapmamalıdır. Hasta hareket ettirildiğinde, ameliyat masasına yeniden pozisyon verildiğinde, pozisyon değişiminden sonra destekler yerleştirildiğinde ve emniyet kemerleri takıldığında hastanın vücudu yeniden değerlendirilmelidir. Sirküle hemşire, pozisyon verme cihazlarının kullanım durumunu, ameliyat sırası kayıtlarına eklemelidir (38).

NPUAP, EPUAP ve PPPIA'nın ortaklaşa çalışmaları ile hazırladıkları rehberde ameliyathanede basınç yaralarının önlenmesine yönelik önerileri bulunmaktadır. Bu öneriler ve kanıt seviyeleri Tablo 5'te verilmiştir (47). 
Tablo 5. Ameliyathanede Basınç Yaralarının Önlenmesine Yönelik NPUAP-EPUAP - PPPIA Önerileri

Öneri Kanıt

Basınç yarası risk grubunda olan hastalar için ameliyat masası üzerinde basıncı Gücü yeniden dağıtan şilteler kullanılmalıdır.

Ameliyat esnasında hastaya basınç yarası oluşum riskini azaltacak şekilde pozisyon verilmelidir.

Hastanın topukları, aşil tendonunu koruyup, bacakların ağırlı̆ı̆ını dağıtacak şekilde elevasyona alınmalı ve hastanın dizleri hafif fleksiyonda olmalıdır.

Ameliyattan önce ve sonra basıncın yeniden dağıtılmasına özen gösterilmelidir. B

Ameliyattan önce ve sonra, hastalar basıncı yeniden dağıtıp azaltan destek yüzeyler üzerine yatırılmalıdır.

Basınç yarası için riskli bireylerde, deriyi korumak amacıyla silikon çok-katlı köpük yara örtüsü kullanılmalıdır.

Topuk bölgesindeki basınç yaralarını önlemek için, önleme yöntemlerine ek olarak profilaktik bir yara örtüsü kullanılmalıdır.

Tıbbi cihazlara bağlı basınç yaralanması riskini azaltmak için, kullanılan tıbbi cihaz altında profilaktik bir örtü kullanılmalıdır.

Ameliyattan önce ve sonra, hastalar ameliyat sırasında olandan farklı pozisyonda yatırılmalidir.

A: Bu öneri, basınç ülseri veya basınç ülseri riski bulunan bireylerde doğru planlanmış ve yapıllmış, kılavuz önerilerini istatistiksel olarak anlamlı sonuçlarla tutarlı bir biçimde destekleyen, randomize kontrollü çalı̧̧aların bilimsel kanıtlarıyla doğrudan desteklenmektedir.

B: Bu öneri, basınç ülseri bulunan bireylerde (veya basınç ülseri riski bulunan bireylerde) doğru planlanmış ve yapılmış, kılavuz önerileri istatistiksel olarak anlamlı sonuçlarla tutarlı bir biçimde desteklenen klinik vaka serilerinden elde edilen bilimsel kanttlarla doğrudan desteklenmektedir.

B1: Doğrudan kanıt sağlayan orta ya da düşük kaliteli Seviye 1 ve doğrudan kanıt sağlayan yüksek ya da orta kaliteli Seviye 2 çalışmaların bilimsel kanıtlarıya desteklenmektedir. Çalışmaların çoğunun tutarlı sonuçları vardır ve tutarsızlıklar açıklanabilmektedir.

$\mathrm{C}: \mathrm{Bu}$ öneri, dolaylı (Örn. sağlıklı gönüllülerde, farklı kronik yarası bulunan bireylerde, hayvan çalışmalarında) kanıtlar ve / veya uzman görüşleri tarafindan desteklenmektedir.

Amerika Ameliyathane Hemşireler Derneği'nin ameliyathanede basınç yaralarını önlemeye yönelik önerileri Tablo 6'da verilmiştir $(46,48)$. 
Tablo 6. Ameliyathanede Hasta Konumlandırmada AORN'un Önerileri

\section{Uygulama Önerileri}

Hastanın basınç yarası gelişim riskine ilişkin ameliyat öncesi değerlendirmesi yapmalıdır.

Hastada bulunan takılar, vücudundaki piersingler, saçındaki aksesuarlar vb. basınç yarası için risk oluşturan diğer tüm eşyalar çıkartılmalıdır.

Hastalar, direkt yüzeysel implante edilmiş veya kritik olan cihazlar üzerine yatırılmamalıdır.

Kritik olan cihazlar*, basıncı azaltıp, cilde zarar vermeyecek biçimde desteklenmeli ve gerekli güvenlik önlemleri alınmalıdır.

Kritik cihazların* sebep olacağı basınç yaralarını önlemek amacıyla koruyucu pansumanlar kullanılabilir.

Koruyucu pansumanlar topuk, sakrum gibi kemik çıkıntılarına, basınç, sürtünme veya makaslama kuvvetine maruz kalan alanlara uygulanabilir.

Multidisipliner bir ekip kullanılacak koruyucu pansumanın türünü belirlemelidir.

Basınç kaynaklı yaralanmaların önlenmesi için kullanılan koruyucu pansumanlar üreticinin talimatlarına göre boyutlandırılmalıdır.

Koruyucu pansumanlar çoklu katman oluşturacak şekilde kullanılmamalıdır.

Hasar görmüş, olması gereken yerden kaymış, gevşemiş ve nemlenmiş koruyucu pansumanlar değiştirilmelidir.

Koruyucu pansumanı olan hastalarda da basınç yaralanmasını önlemeyi amaçlayan güvenli pozisyon verme uygulamalarına devam edilmelidir.

Pozisyon ekipmanları, cihazlar ve destek yüzeyler kullanım öncesi temizlenmeli, yüzey bütünlüğü kontrol edilip, doğru çalıştığından emin olunmalıdır.

Pozisyon araçları ve destek yüzeyler, üretici firmanın önerilerine uygun kullanılmalıdır.

Hastaların yerleştirildiği yüzeyler, kırışık olmamalı, katlanmamalı ve pürüzsüz olmalıdır.

Hastalar çok katmanlı çarşaf veya battaniye gibi malzemelere yerleştirilmemelidir.

Hastalar mümkünse isıtıcı battaniye üzerine yerleştirilmemelidir.

Hastalar basıncı yeniden dağıtabilen yüzeyler üzerine yerleştirilmelidir.

Hastalara pozisyon vermek için, çarşaf, battaniye veya havlu benzeri malzemeler

kullanılmamalıdır.

Mümkünse, basınç yarası riski yüksek olan tüm hastalar, yüksek özellikli reaktif sünger yüzeyler üzerine yerleştirilmelidir.

Hastalara pozisyon verirken topuklar yükseltilerek yüzey ile teması kesilmelidir.

Hastanın vücudunun ameliyat masasının metal ve sert yüzeyleri ile olan teması önlenmelidir.

Hastanın elleri, parmakları, ayak ve ayak parmakları, cinsel organları, pozisyon verme işlemi sırasında gözlenmelidir.

Tansiyon aletleri manşetleri ve puls oksimetre sensörleri gibi hasta izlemi için kullanılan cihazlar, hastada doku, sinir ya da dolaşım hasarına sebep olmadan, etkili bir şekilde çalışır durumda olmalidir.

Hastanın emniyet kemerleri bağlandıktan sonra, ilgili nabızları değerlendirilmelidir.

Hastanın spinal kordda lezyonu varsa, lezyon üzerinde direkt baskıyı önleyerek pozisyon verilmelidir.

Steril alanda bulunan cerrahi ekip hastaya yaslanmamalıdır.
Kanit gücü

1: Güçlü Kanıt
3: Orta Kanıt

1: Güçlü Kanıt

1: Güçlü Kanıt

1: Güçlü Kanıt

2: Yüksek Kanıt

2: Yüksek Kanıt

3: Orta Kanit

3: Orta Kanit

1: Güçlü Kanıt

1: Güçlü Kanıt

1: Güçlü Kanıt

3: Orta Kanit

2: Yüksek Kanıt

1: Güçlü Kanıt

3: Orta Kanıt

1: Güçlü Kanıt

3: Orta Kanıt

1: Güçlü Kanıt

1: Güçlü Kanıt

3: Orta Kanit

3: Orta Kanıt

3: Orta Kanıt

3: Orta Kanit

3: Orta Kanıt

3: Orta Kanıt

* Endotrakeal tüp, turnike, varis çorabı, üriner kateter, tansiyon manşonu gibi basınç oluşturabilecek cihazlar.

\section{Sonuç}

Basınç yaraları, sağlık sistemindeki gelişme ve yeniliklere karşın, hala hasta ve sağlık çalışanları için önemli bir sorundur. Cerrahi girişim uygulanan hastalarda basınç yarası gelişimine neden olan birçok risk faktörü bulunmaktadır. Ameliyathanede cerrahi girişim ön planda olduğundan basınç yarasına yol açabilecek risk faktörleri ve dolayısıyla önleme girişimleri göz ardı edilebilmektedir. Basınç yaralanmalarını önlemek ve olumsuz etkilerini azaltmak için, basınç yarasına neden olabilecek risk faktörlerinin geçerli bir ölçekle doğru değerlendirilmesi önemlidir. Cerrahi hemşireleri ve ameliyathane hemşireleri basınç yaralarının önlenmesinde kanıta dayalı önerilerin uygulanması konusunda liderlik etmelidir. Ameliyathanede basınç yaralarının önlenmesi ile ilgili güncel literatür izlenmeli ve tüm ekibe basınç yaralarını önleme konusunda düzenli eğitimler planlanmalıdır.

\section{Bilgilendirme}

$\mathrm{Bu}$ derlemede herhangi bir potansiyel çıkar çatışması bulunmamaktadır. Derlemede araştırma ve yayın etiğine uyulmuştur. Derlemenin hazırlanmasına tüm yazarlar katkıda bulunmuştur. Derlemenin fikir, tasarım, yazım ve eleştirel incelemesine A.S katkı sağlamıştır. Derlemenin fikir ve tasarım, literatür taraması ve yazım aşamasında E.A katkı sağlamıştır. Derlemenin literatür taraması, yazım ve eleştirel incelemesine K.K katkı sağlamıştır. Yazarlar bu çalışmadan herhangi bir mali destek almamıştır. Bu derleme daha önce hiçbir dergide yayınlanmamış, yayınlanmak üzere kabul edilmemiş ve değerlendirme altına alınmamıştır. 


\section{Kaynaklar}

1. Edsberg LE, Black JM, Goldberg M, McNichol L, Moore L, Sieggreen M. Revised national pressure ulcer advisory panel pressure injury staging system: Revised pressure injury staging system. J Wound Ostomy Continence Nurs. 2016 Nov/Dec;43(6):585-597. doi: 10.1097/WON.0000000000000281. PMID: 27749790; PMCID: PMC5098472.

2. Ünver S, Y1ldırım M, Akyolcu N, Kanan N. Concept analysis of pressure sores: Florence Nightingale Journal of Nursing. 2015;22(3):168-171.

3. Benevides JL, Coutınho JVF, Tomé MABG, Gubert FA, Sılva TBC, Olıveira SKPO. Nursing strategies for the prevention of pressure ulcers in intensive therapy: integrative review. Journal of nursing ufpe 2017;11(5):19431952. doi: 10.5205/1981-8963-v11i5a23344p1943-1952-2017

4. Agrawal K, Chauhan N. Pressure ulcers: Back to the basics. Indian J Plast Surg 2012 May;45(2):24454. doi: 10.4103/0970-0358.101287. PMID: 23162223; PMCID: PMC3495374.

5. Mervis JS, Phillips TJ. Pressure ulcers: Pathophysiology, epidemiology, risk factors and presentation. J Am Acad Dermatol 2019 Oct;81(4):881-890. doi: 10.1016/j.jaad.2018.12.069. Epub 2019 Jan 18. PMID: 30664905.

6. Becker D, Tozo TC, Batista SS, Mattos AL, Silva MCB, Rigon S, et al. Pressure ulcers in ICU patients: Incidence and clinical and epidemiological features: A multicenter study in southern Brazil. Intensive and Critical Care Nursing 2017;42(10):55-61.

7. El-Marsi J, Zein-El-Dine S, Zein B, Doumit R, Kurdahi Badr L. Predictors of Pressure Injuries in a Critical Care Unit in Lebanon: Prevalence, Characteristics, and Associated Factors. J Wound Ostomy Continence Nurs. 2018 Mar/Apr;45(2):131-136. doi: 10.1097/WON.0000000000000415. PMID: 29521923.

8. Ülker Efteli E, Güneş Ü. Basınç yarası gelişiminde perfüzyon değerlerinin etkisi: Anadolu Hemşirelik ve Sağlık Bilimleri Dergisi 2014;17(3):0-.

9. Kaşıķ̧ı M, Aksoy M, Ay E. Investigation of the prevalence of pressure ulcers and patient-related risk factors in hospitals in the province of Erzurum: A cross-sectional study. J Tissue Viability 2018 Aug;27(3):135-140. doi: 10.1016/j.jtv.2018.05.001. Epub 2018 May 16. PMID: 29776817.

10. Katran HB. The research on the incidence of pressure sores in a surgical intensive care unit and the risk factors affecting the development of pressure sores: Journal of Academic Research In Nursing 2015;1(1):8-14. doi: 10.5222/jaren.2015.008

11. Tanrıkulu F, Dikmen Y, Tanrıkulu F. Yoğun bakım hastalarında basınç yaraları, risk faktörleri ve önlemler: Journal of Human Rhythm 2017;3(4):177-182.

12. Association of Perioperative Registered Nurses. Position statement on perioperative pressure ulcer prevention in the care of the surgical patient. AORN Journal 2016;104(5):437-438.21. http://www.aorn.org/aorn-org/guidelines/

13. Gefen A. How much time does it take to get a pressure ulcer? Integrated evidence from human, animal, and in vitro studies. Ostomy Wound Manage 2008 Oct;54(10):26-8,30-5. PMID: 18927481.

14. Menezes S, Rodrigues R, Tranquada R, Müller S, Gama K, Manso T. Lesões decorrentes do posicionamento para cirurgia: incidência e fatores de risco [Injuries resulting from positioning for surgery: incidence and risk factors]. Acta Med Port 2013 Jan-Feb;26(1):12-6. Portuguese. Epub 2013 Apr 24. PMID: 23697352.

15. Bulfone G, Marzoli I, Quattrin R, Fabbro C, Palese A. A longitudinal study of the incidence of pressure sores and the associated risks and strategies adopted in Italian operating theatres. JPerioperPract 2012;22(2):50-12. Availablefrom: https:// www. ncbi. nlm. nih. gov/ pubmed/ 22724304

16. Saraiva IL, Paula MFC, Carvalho R. Pressure ulcer in the transoperative period: occurrence and associated factors. Rev SOBECC 2014;19 (4):207-13.

17. Celik B, Karayurt Ö, Ogce F. The effect of selected risk factors on perioperative pressure injury development. AORN J 2019 Jul;110(1):29-38. doi: 10.1002/aorn.12725. PMID: 31246295.

18. Ter N, Yavuz van Giersbergen M. Basınç yaralarının önlenmesi, Ameliyathane Hemşireliği Kitabı: Yavuz van Gıersbergen M., Kaymakçı Ş., İzmir; Meta Basım ve Matbaacılık Hizmetleri 2015;483 - 488.

19. Spruce L. Back to basics: Preventing perioperative pressure injuries. AORN J 2017 Jan;105(1):92-99. doi: 10.1016/j.aorn.2016.10.018. PMID: 28034406.

20. Huang HY, Chen HL, Xu XJ. Pressure-redistribution surfaces for prevention of surgery-related pressure ulcers: A meta-analysis. Ostomy Wound Manage 2013 Apr;59(4):36-8,42, 44, 46, 48. PMID: 23562873.

21. de Oliveira KF, Nascimento KG, Nicolussi AC, Chavaglia SRR, de Araújo CA, Barbosa MH. Support surfaces in the prevention of pressure ulcers in surgical patients: An integrative review. Int J Nurs Pract 2017 Aug;23(4). doi: 10.1111/ijn.12553. Epub 2017 Jun 23. PMID: 28643855.

22. Lumbley JL, Ali SA, Tchokouani LS. Retrospective review of predisposing factors for intraoperative pressure ulcer development. J Clin Anesth 2014 Aug;26(5):368-74. doi: 10.1016/j.jclinane.2014.01.012. Epub 2014 Aug 10. PMID: 25113424.

23. Chen HL, Chen XY, Wu J. The incidence of pressure ulcers in surgical patients of the last 5 years: A systematic review. Wounds 2012 Sep;24(9):234-41. PMID: 25874704.

24. Scarlatti KC, Marlene- Michel JL, Gamba MA, Rivero de Gutiérrez MG. Pressure soress in surgery patients incidence and associated factors. Revista da Escola de Enfermagem da USP 2011; 45(6):1369-1375.

25. Edsberg LE, Langemo D, Baharestani MM, Posthauer ME, Goldberg M. Unavoidable pressure injury state of the science and consensus outcomes. J Wound Ostomy Continence Nurs 2014;41(4):313-334.

26. Fred C, Sharonford C, Doreenwagner C, Vanbrackle CL. Intraoperatively acquired pressure soress andperioperative normothermia: A look at relationships. AORN Journal 2012;96(3): 251-260. 
27. Yusuf S, Okuwa M, Shigeta Y, Dai M, Luchi T, Rahman S, et al. Microclimate and development of pressure soress and superficial skin changes. International Wound Journal 2013;40-46.

28. Yoshimura M, Iizaka S, Kohno M, Nagata O, Yamasaki T, Mae T, Haruyama N, Sanada H. Risk factors associated with intraoperatively acquired pressure ulcers in thepark-bench position: A retrospective study. Int Wound $\mathbf{J}$ 2016;13:1206-1213.

29. Angmorterh SK, England A, Webb J, Szczepura K, Stephens M, Anaman-Torgbor J, et al. An investigation of pressure ulcer risk, comfort, and pain in medical imaging. Journal of Medical Imaging and Radiatiom Science 2019;50(1), 43-52. doi: 10.1016/j.jmir.2018.07.003

30. Hayes RM, Spear ME, Lee SI, Krauser Lupear BE, Benoit RA, Valerio R, Dmochowski RR. Relationship between time in the operating room and incident pressure ulcers: A matched case-control study. Am J Med Qual 2015 NovDec;30(6):591-7. doi: 10.1177/1062860614545125. Epub 2014 Jul 30. PMID: 25077711.

31. Wright KM, Van Netten Y, Dorrington CA, Hoffman GR. Pressure injury can occur in patients undergoing prolonged head and neck surgery. J Oral Maxillofac Surg 2014 Oct;72(10):2060-5. doi: 10.1016/j.joms.2014.04.018. Epub 2014 Apr 24. PMID: 25053571.

32. Khong BPC, Goh BC, Phang LY, David T. Operating room nurses' self reported knowledge and attitu de on perioperative pressure injury. International Wound Journal 2020;17(2), 455-465. doi: 10.1111/iwj.13295.

33. Monahan FD, Sands JK, Neighbors M, Maker JF, Green CJ. (2006). Phipps Medical Surgical Nursing.(8. Bask1)

34. Çınar F, Kula Şahin S, Eti Aslan F. Evaluation of studies in turkey on the prevention of pressure sores in the intensive care unit: A systematic review. Health Science Journal 2018;7(1):42-50.

35. Soyer Ö, Özbayır T. 3S Ameliyathane Basınç Yarası Risk Tanılama Ölçeği’nin Türkçe’ye Uyarlanması. Uluslararası Hakemli Hemşirelik Araştırmaları Dergisi Mayıs / Haziran / Temmuz / A ğustos İlkbahar Yaz Dönemi 2018;Say1:13 Doi: 10.17371/UHD.2018.2.9

36. Registered Nurses' Association of Ontario- RNAO. Assesment and Management of Pressure Injuries for the Interprefossional Team Third Edition. Toronto: Registered Nurses' Association of Ontario Publishing 2016. http://www.rnao.ca/bpg

37. Avşar P, Karadağ A. Waterlow Basınç Ülseri Risk Değerlendirme Ölçeği’nin Türkçeye Uyarlanması, GeçerlikGüvenirlik Çalışması. Hacettepe Üniversitesi Hemşirelik Fakültesi Dergisi 2016;3(3):1-15.

38. Association of PeriOperatif Registered Nurses. Guideline for Positioning the Patient. Wahl RL, ed. Perioperative Standards and Recommended Practices. Denver: CO 2015;p.563-81.

39. Haesler E, editör. Prevention and Treatment of Pressure Ulcers: Quick Reference Guide. Individuals in the operatıng room. Cambridge Media: Osborne Park, Australia 2014;57-59.

40. Karacabay K. Pozisyon verme. Yavuz van Giersbergen M, Kaymakçı Ş. Ameliyathane Hemşireliği. İzmir: Meta Basım ve Matbaacılık Hizmetleri 2015;p.459-76.

41. Engels D, Austin M, McNichol L, Fencl J, Gupta S, Kazi H. Pressure ulcers: factors contributing to their development in the OR. AORN J 2016;103(3):271-281

42. Song JB, Vemana G, Mobley JM, Bhayani SB. The second "timeout": a surgical safety checklist for lengthy robotic surgeries. Patient Saf Surg 2013;7(1):19.

43. Gül Ş. Cerrahi girişim uygulanan hastalarda basınç ülseri gelişiminin önlenmesi. Hacettepe Üniversitesi Hemşirelik Fakültesi Dergisi 2014;54-61.

44. Çelik S, editör. Taşdemir N, Yard. Editör. Güncel Yöntemlerle Cerrahi Hastalıklarda Bakım. Çukurova Nobel Tıp Kitaevi 2018; (s.43-74).

45. Eyi S, Kanan N, Akyolcu N. Ameliyat sırası dönemde kaliteli hemşirelik bakımına ulaşmada hemşirenin rolü. F.N. Hem. Derg 2017;25(2): 126-138.ISSN 2147-4923 Derleme Makalesi

46. Guideline for positioning the patient. In: Guidelines for Perioperative Practice. Denver, CO: AORN, Inc; 2018:673- 744. https://www.guidelinecentral.com/summaries/guideline-for-positioning-the-patient/ Erişim Tarihi: 17.02.2021

47. European Pressure Ulcer Advisory Panel, National Pressure Injury Advisory Panel and Pan Pacific Pressure Injury Alliance. Basınç Ülserlerinin/Yaralarının Önlenmesi ve Tedavisi: Hızlı Başvuru Kılavuzu 2019. (Türkçe versiyon).Emily Haesler (Ed.). EPUAP/NPIAP/PPPIA: 2019.

48. Association of PeriOperative Registered Nurses (AORN). (2019). Positioning the Patient. Guidelines For Perioperative Practice 2019 Edition. Editor: Wood A, Denver CO. Canada. 637-713. 